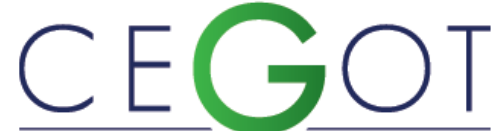

Centro de Estudos de Geografia e Ordenamento do Território
NEVES, RAFAEL

Universidade Estadual do Norte Fluminense Darcy Ribeiro/UENF

Av. Alberto Lamego, no 2000, Pq. Califórnia, Cep 28013-602, Campos dos Goytacazes, Brasil rafaelmneves@hotmail.com

\section{FARIA, TERESA}

Universidade Estadual do Norte Fluminense Darcy Ribeiro/UENF

Av. Alberto Lamego, no 2000, Pq. Califórnia, Cep 28013-602, Campos dos Goytacazes, Brasil teresa.uenf@gmail.br

\title{
Impactos da indústria do petróleo e a condição de injustiça ambiental nas cidades pequenas petrorentistas de Carapebus e Quissamã
}

Impacts of the oil industry and the condition of environmental injustice in the small petrorentistas cities of Carapebus and Quissamã

Referência: Neves, Rafael; Faria, Teresa (2019). Impactos da indústria do petróleo e a condição de injustiça ambiental nas cidades pequenas petrorentistas de Carapebus e Quissamã. Revista de Geografia e Ordenamento do Território (GOT), no 18 (Dezembro). Centro de Estudos de Geografia e Ordenamento do Território, p. 78-107, dx.doi.org/10.17127/got/2019.18.004

\section{RESUMO}

O presente texto propõe analisar os impactos da indústria do petróleo e a promoção de justiça ambiental sobre o espaço urbano de Carapebus e de Quissamã, cidades pequenas localizadas no Norte Fluminense, mesorregião do estado do Rio de Janeiro. Entre os anos 2000 até 2018, tais cidades receberam vultosos repasses de rendas petrolíferas, que ao menos em tese, poderiam proporcionar a mitigação das demandas relacionadas ao incremento populacional superior a $77 \%$ nesse período. Procurando contribuir com os estudos relacionados às cidades pequenas impactadas pela indústria do petróleo na Bacia de Campos, evidencia-se a condição de injustiça ambiental em novos eixos de expansão urbana nas sedes municipais de Carapebus e de Quissamã.

Palavras-chave: Impactos da Indústria do Petróleo; Justiça Ambiental; Cidades Pequenas; Carapebus; Quissamã.

\section{ABSTRACT}

The present text proposes to analyze the impacts of the oil industry and the promotion of environmental justice on the urban space of Carapebus and Quissamã, small cities located in the North Fluminense, mesoregion of Rio de Janeiro state. Between the years 2000 and 2018, these cities received large transfers of oil rents, which, at least in theory, could provide mitigation of demands related to the population increase of more than $77 \%$ during this period. Seeking to contribute to the studies related to the small towns impacted by the oil industry in the Campos Basin, the condition of environmental injustice in the new axes of urban expansion in the municipal headquarters of Carapebus and Quissamã.

Keywords: Impacts of the Oil Industry; Environmental Justice; Small Cities; Carapebus; Quissamã. 


\section{Introdução}

No Brasil, a classificação oficial do que é uma cidade segue o parâmetro políticoadministrativo, conforme determinação válida até a elaboração deste artigo do Decreto-Lei 311/1938, no qual toda a sede municipal é considerada uma cidade, sem a observância das suas peculiaridades estruturais e funcionais. Crítico dessa perspectiva legal, Veiga (2002) é um expoente no debate sobre a real proporção do urbano no país, pois entende que os critérios utilizados mascaram a realidade, já que nem todas as sedes municipais são necessariamente espaços urbanos. Isso se torna mais latente nas cidades pequenas, onde é possível observar o rural para além do campo, ou seja, no dia a dia dos moradores que vivem nessas "cidades".

Ainda que na literatura e nos organismos oficiais de diversos países propague-se a discussão sobre os critérios de definição do que é uma cidade, não havendo convenção definida, predominam distintos parâmetros, tais como: número de habitantes, disponibilidade de equipamentos urbanos e decisão político-administrativa (Silva; Gomes; Silva, 2009). Nesse sentido, utilizando o critério populacional, reconhece que as cidades pequenas compõem a maior parte da rede urbana nacional. Dentre os 5.570 municípios do país, a maior parte apresenta população inferior a 50 mil habitantes, onde vivem aproximadamente 62 milhões de brasileiros, população maior do que a de países como Argentina ou Colômbia (Jurado da Silva; Sposito, 2013).

O interesse em pesquisar as cidades pequenas surgiu como forma de contribuir para a reversão da condição de pouca visibilidade nos estudos urbanos sobre essa categoria de cidades na esfera da academia que, tradicionalmente, prioriza os estudos relacionados às cidades médias e grandes (ENDLICH, 2009). Desde a década de 1980, autores como Milton Santos (1982) e Roberto Lobato Corrêa (1989) evidenciaram a relevância das pesquisas sobre as cidades pequenas. É válido destacar que grupos de pesquisa como o GAPERR ${ }^{29}$ e o GPEUR $^{30}$, entre outros, apresentam abordagens recentes sobre o tema, o que demonstra

\footnotetext{
${ }^{29}$ Grupo de Pesquisa Produção do Espaço e Redefinições Regionais (GAPERR) ligado ao Programa de PósGraduação em Geografia da Universidade Estadual Paulista de Presidente Prudente.

${ }^{30}$ Grupo de Pesquisa em Estudos Urbanos e Regionais (GPEUR) ligado ao Programa de Pós-Graduação em Estudos Regionais da Universidade Federal do Rio Grande do Norte.
} 
um esforço de elevar e manter as cidades pequenas como importante objeto de pesquisa na universidade.

No contexto brasileiro, os entes federados inseridos em áreas petrolíferas são beneficiados economicamente pelas regras de divisão das rendas obtidas pela exploração e produção (E\&P) desse hidrocarboneto, que apresenta crescente evolução, sobretudo, após o início da exploração das reservas localizadas no chamado "pré-sal ${ }^{31 "}$, estabelecidas entre o litoral dos estados do Espírito Santo, Rio de Janeiro, São Paulo e Paraná. O pré-sal é considerado uma nova fronteira energética que concentra as seis maiores reservas descobertas desde 2008 no mundo, elevando o Brasil à condição de 60 país com maior reserva de petróleo (Pessanha, 2017).

Buscando compreender os impactos dessa cadeia produtiva, foi definido com campo privilegiado de observação a primeira área consolidada de E\&P, a Bacia de Campos ${ }^{32}$, localizada no litoral norte do estado do Rio de Janeiro, mesorregião geográfica do Norte Fluminense, onde os desdobramentos dessa atividade econômica a partir da década de 2000, período em que os municípios brasileiros passaram a receber royalties e participações especiais como compensação às implicações ambientais, econômicas e sociais das atividades desenvolvidas pelo setor petrolífero. A Bacia de Campos, que já chegou a concentrar $84 \%$ da produção de petróleo nacional, atualmente responde por $45 \%$ da produção de petróleo e $19 \%$ da produção de gás natural, sendo ultrapassada em volume de produção pela Bacia de Santos, com predominância da E\&P em áreas do pré-sal (ANP, 2018).

Dos nove municípios que compõem o Norte Fluminense, dois se inserem no debate sobre as cidades pequenas e os impactos das rendas petrolíferas por apresentarem reduzido contingente populacional e por figurarem entre os municípios que mais recebem repasses das rendas petrolíferas: Carapebus e Quissamã. Segundo o Instituto Brasileiro de Geografia

\footnotetext{
${ }^{31}$ As reservas do pré-sal estão localizadas no litoral das regiões sudeste e sul do Brasil, a uma profundidade média de 6.000 metros, após espessa camada de rochas e sal no subsolo marítimo. Ainda que o termo tenha relação originária com a estrutura e processos geológicos, neste artigo sua conotação está relacionada às potencialidades econômicas dessa reserva petrolífera.

${ }^{32}$ A Bacia de Campos é importante província petrolífera explorada na costa brasileira. Essa bacia sedimentar se estende das imediações da cidade de Vitória (estado do Espírito Santo) até a cidade de Arraial do Cabo, no litoral do estado do Rio de Janeiro, em uma área de aproximadamente 100 mil quilômetros quadrados (PETROBRAS, 2019).
} 
e Estatística - IBGE (2018), tais municípios apresentam população e densidade demográfica de 16 mil e 24 mil habitantes, respectivamente 28,40 hab./ $\mathrm{km}^{2}$ e 43,36 hab./ $\mathrm{km}^{2}$. A Figura 1 apresenta a localização dessas cidades no Estado do Rio de Janeiro.

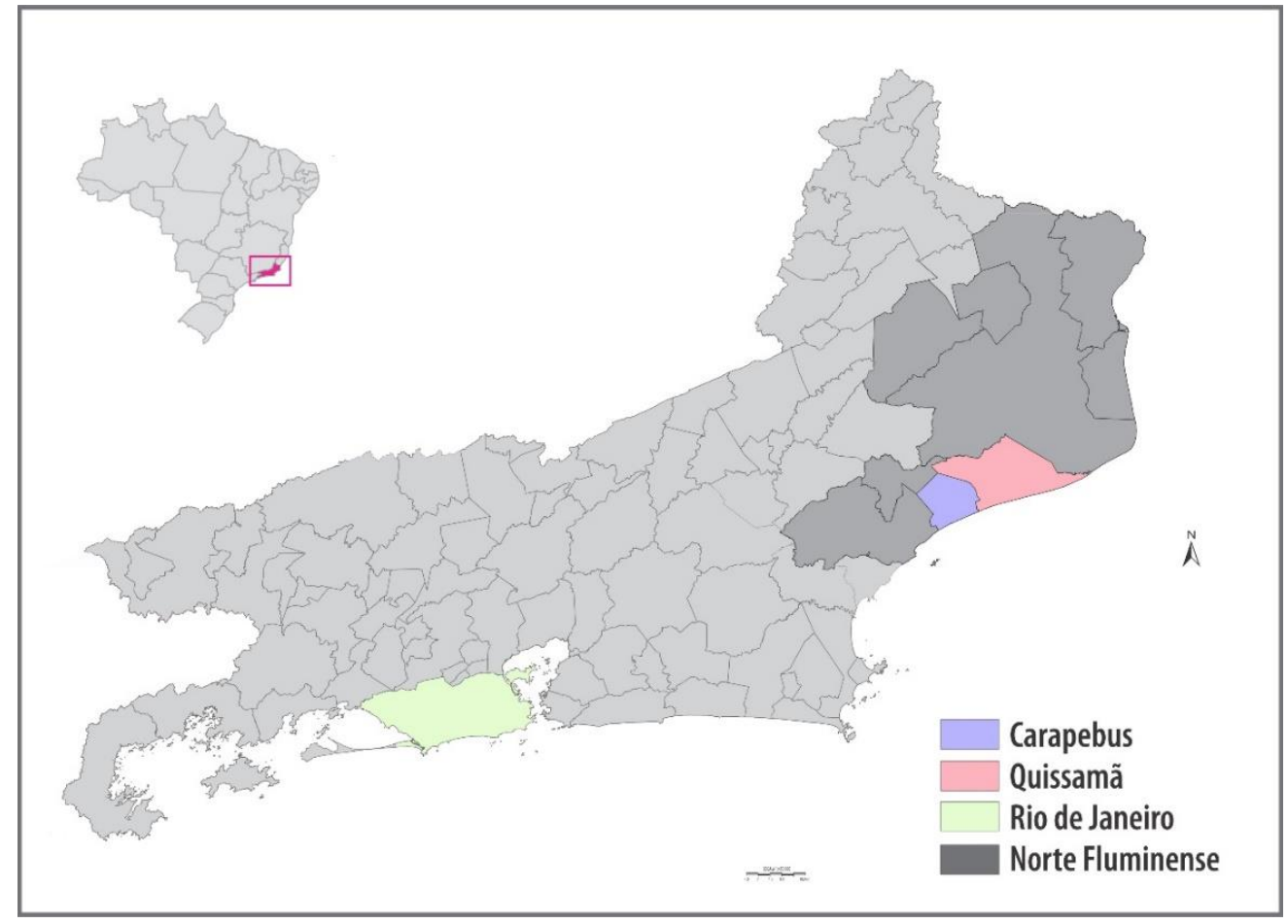

Fig. 1 - Localização dos municípios de Carapebus e Quissamã/RJ.

Fonte: Mapa adaptado pelos autores a partir de CEPERJ (2018).

Nesse cenário, emerge o objetivo desse artigo, que é o de analisar como Carapebus e Quissamã, cidades pequenas do Norte Fluminense, foram impactadas em seu espaço urbano pela indústria do petróleo à luz do debate sobre a justiça ambiental, constituindo um exercício de reconhecimento dos efeitos da indústria petrolífera para além das cidades médias polarizadoras da mesorregião: Campos dos Goytacazes e Macaé. Outras cidades pequenas que poderão ser beneficiadas pelas rendas petrolíferas do pré-sal, provavelmente, terão na área mais antiga e historicamente de maior de produção do país, a Bacia de Campos, um importante campo de observação de experiências exitosas ou malogradas provenientes das dinâmicas dessa cadeia produtiva.

A produção petrolífera nessa região alterou significativamente a sua estrutura econômica, social e territorial, desdobrando-se em novos e diferentes impactos nos municípios localizados no Norte Fluminense. Tais mudanças iniciaram-se na década de 1970, quando a Petrobras estabeleceu suas atividades de E\&P de petróleo e gás natural na plataforma 
continental no litoral da mesorregião. Macaé foi definida como base das atividades da Petrobras na Bacia de Campos, transformando-se no polo irradiador das mudanças observadas nessa porção territorial (Serra, 2007).

A década de 1990 foi um período no qual tais mudanças se mostraram mais intensas. A "febre emancipatória" ${ }^{33}$, vivenciada no Brasil a partir da promulgação da Constituição Federal de 1988, também apresentou desdobramentos regionais. Dos dez municípios que compõem atualmente o Norte Fluminense, quatro tiveram a sua efetiva instalação na referida década ${ }^{34}$. Porém, é válido destacar que, no caso em tela, o recebimento de royalties da atividade petrolífera também se configurou em mais um motivo para a emancipação desses municípios que viam nessa fonte de renda novas possibilidades de ação dos recémemancipados entes federados.

As possibilidades de emprego proporcionadas pela indústria do petróleo, ainda que concentradas, principalmente, em Macaé e o "enriquecimento" dos municípios que estão posicionados na zona de produção primária da Bacia de Campos $^{35}$ tornaram o Norte Fluminense um polo de atração populacional de amplitude nacional (Paganoto, 2008). Juntamente com as rendas petrolíferas, a evolução populacional em voga pode ser entendida como importante impacto da indústria do petróleo na mesorregião, criando um quadro de possibilidades e desafios aos municípios que a compõe.

Franks (2012), ao analisar os impactos promovidos pela indústria do petróleo em cidades da Austrália, ressalta que, embora ocorram os impactos negativos ao meio ambiente, às comunidades e à economia local, a atuação do poder público, da sociedade civil e das empresas ligadas à atividade de E\&P petrolífera pode reverter, ao menos em parte, esses efeitos, transformando-os em positivos, com a oferta de novos postos de empregos, maior disponibilidade financeira das esferas governamentais, ampliação de infraestrutura, entre outros. Quanto ao meio ambiente, é impossível citar, nesse caso, impactos positivos, mas a

\footnotetext{
${ }^{33}$ Termo utilizado por Piquet (2002, p. 6) apud Cruz e Pinto (2007, p. 322) ao se referir às diversas emancipações que ocorreram após a promulgação da Constituição Federal de 1988.

${ }^{34}$ São eles: Quissamã (1990), Cardoso Moreira (1993), São Francisco do Itabapoana (1997) e Carapebus (1998).

${ }^{35}$ Determinada pelo IBGE, é a área mais próxima dos campos de produção de petróleo.
} 
mobilização política e social pode criar medidas que mitiguem os danos causados pela indústria do petróleo.

No caso dos municípios inseridos na zona de produção primária da Bacia de Campos, entende-se como possibilidade o recebimento de vultosas rendas petrolíferas, que coloca esse grupo de cidades como os que mais recebem royalties e participações especiais no país e que gozam de condição orçamentária bem mais favorável que a média das demais cidades pequenas brasileiras (Santos, 2017). As oportunidades criadas por tais rendas permitiriam, ao menos em teoria, a implementação de políticas públicas frente aos problemas enfrentados por seus habitantes, tornando tais entes potenciais "municípios modelo".

Entende-se que a configuração e a produção do espaço urbano das cidades em perspectiva devem ser investigadas considerando o contexto de sobrefinanciamento orçamentário proporcionado pelas rendas petrolíferas. Em linhas gerais, o processo de urbanização pode ser compreendido como a ocupação e concentração populacional no espaço geográfico e o estabelecimento do seu sistema de valores, atitudes e comportamento social, ou seja, a "cultura urbana". Ademais, o espaço urbano será explorado para além dessa interpretação, destacando o papel do poder executivo local como agente indutor de condições consideradas de injustiça ambiental.

\section{O caminho metodológico percorrido}

Este artigo é um desdobramento de pesquisa elaborada no âmbito do Projeto Territórios do Petróleo $^{36}$, com ênfase nos núcleos urbanos de Carapebus e de Quissamã. As atividades desenvolvidas por esse projeto objetivam criar ambientes de encontro e diálogo entre os munícipes, com pauta direcionada às questões referentes aos royalties do petróleo. Os dados utilizados neste artigo foram coletados a partir de reuniões e expedições que ocorreram entre os meses de janeiro de 2015 e agosto de 2016, sendo retomadas em março

\footnotetext{
${ }^{36}$ Segundo a Petrobras (2012), o “Projeto Territórios do Petróleo" visa a promover discussão pública dos processos de distribuição e aplicação dos royalties e participações especiais, incentivar a constituição de Núcleos de Vigília Cidadã e realizar ações e/ou atividades educativas, tendo como público prioritário os representantes dos grupos sociais mais vulneráveis aos impactos da indústria do petróleo. Visa a beneficiar, nas suas atividades abertas, membros da sociedade civil organizada, com posições sociais e lideranças nos municípios de atuação do projeto. Os municípios contemplados pelo projeto são: Arraial do Cabo, Cabo Frio, Armação dos Búzios, Casimiro de Abreu, Rio das Ostras, Macaé, Carapebus, Quissamã, Campos dos Goytacazes e São João da Barra.
} 
de 2018 com o prosseguimento da pesquisa atrelada ao Programa de Doutorado em Políticas Sociais da Universidade Estadual do Norte Fluminense Darcy Ribeiro (UENF). Tal participação se mostrou duplamente positiva: permitiu a interação e a construção de laços mais efetivos com os moradores e possibilitou o reconhecimento da questão dos royalties pelo ponto de vista dos próprios munícipes.

A partir dessa interação, foi possível reconhecer os principais eixos de expansão urbana recente das cidades, além dos problemas urbanos que mais afligem os seus moradores. 0 registro dessas informações, por meio do diário de campo, permitiu criar um roteiro da verificação in loco das informações obtidas que, posteriormente, subsidiou a sistematização do roteiro das entrevistas aplicadas aos moradores e gestores públicos. Para tanto, na composição da amostra, foi adotado o método não probabilístico bola de neve, no qual se priorizou a escolha de participantes que tivessem reconhecido saber sobre a história do município e histórico de atuação comunitária. O critério de seleção desses participantes se pautou na indicação dos próprios moradores.

Nesse sentido, foram definidas quatro categorias de entrevistados, a saber: o líder comunitário, o historiador, o morador e o gestor público. O líder comunitário representa o munícipe que desempenha ações de integração e de influência na comunidade em que vive, sendo priorizada a indicação de líder comunitário de bairro com expressivo crescimento demográfico nos últimos anos. O historiador representou o munícipe que desenvolveu ações de resgate e divulgação da história local, valorizando a perspectiva do pesquisador local. O morador, o munícipe que acabou por não atuar de uma maneira mais efetiva com a mobilização comunitária da cidade, mas que apresentou interpretações próprias sobre as questões levantadas. Já o gestor público representou a visão do poder público local ${ }^{37}$. A Figura 2 apresenta esquema que exemplifica organização dessa etapa da pesquisa de campo.

Os dados obtidos na interação com os munícipes e com as entrevistas realizadas foram analisados por meio da caracterização da realidade socioeconômica de Carapebus e de Quissamã. Assim, foram trabalhados indicadores demográficos, da composição do IDH-M e do recebimento e da dependência orçamentária das rendas petrolíferas, com a pretensão

\footnotetext{
${ }^{37}$ Ao todo, foram realizadas oito entrevistas, além de abordagens informais e aleatórias aos moradores dos bairros considerados de expansão urbana recente no segundo semestre de 2015 e primeiro semestre de 2016.
} 
de se estabelecer parâmetro de comparação entre as realidades das cidades em voga e com os demais municípios do Norte Fluminense. Todo esse debate foi norteado considerando a condição desses municípios como recebedores de royalties e participações especiais da indústria petrolífera.

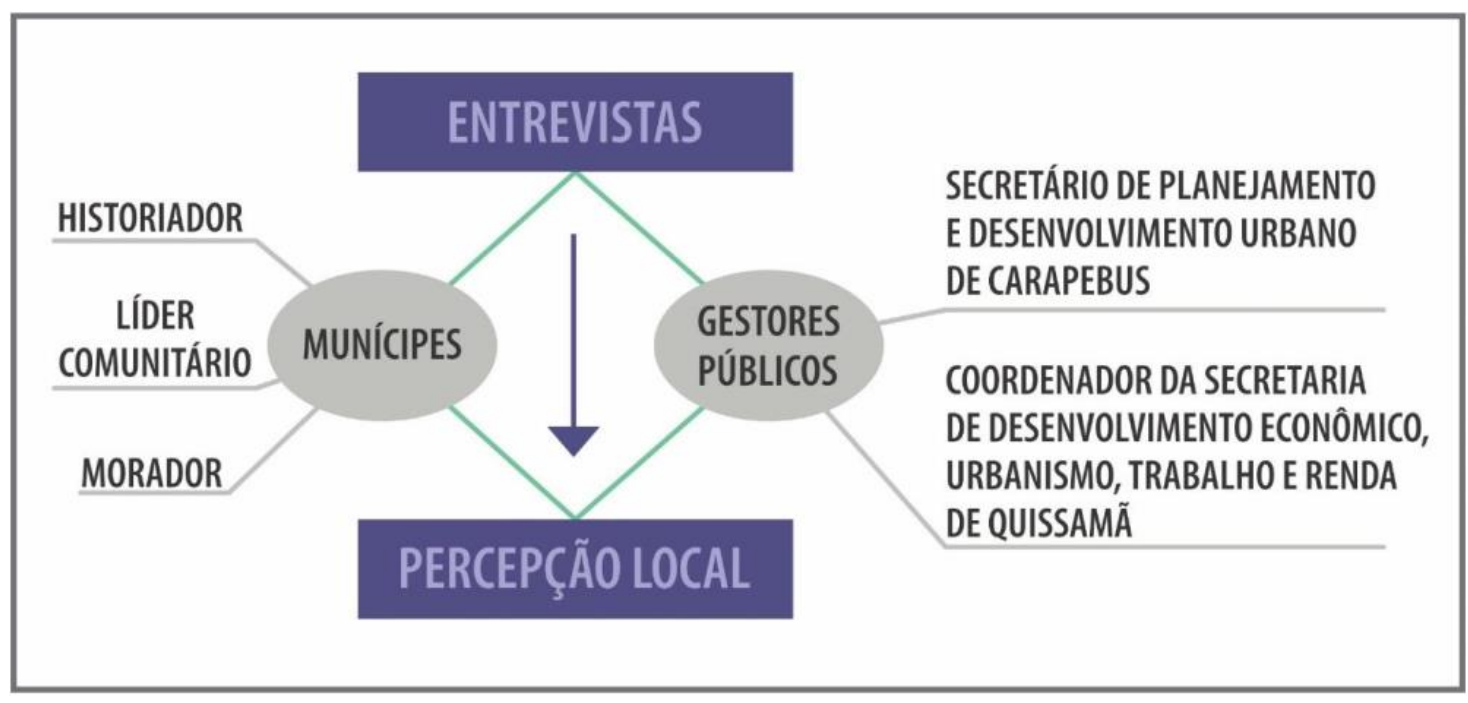

Fig. 2 - Organização das entrevistas

Fonte: Ilustração elaborada pelos autores.

Valendo-se dos registros fotográficos colhidos no campo e com os dados obtidos, foram elaborados quadros-síntese que englobassem as questões relacionadas aos impactos ambientais nos novos eixos de expansão urbana. Com auxílio de imagens de satélite, foram construídos mapas com a identificação de tais eixos. Dessa forma, a pesquisa buscou demonstrar os desdobramentos da indústria petrolífera na sede municipal dessas cidades, permitindo a caracterização da realidade do espaço urbano de cada realidade e evidenciando o que é considerado aspectos da injustiça ambiental.

Com a prevalência de abordagem qualitativa, o exercício da interpretação do campo teve o foco na visão dos sujeitos inseridos nas realidades analisadas, destacando suas opiniões, percepções e anseios. É válido ressaltar que a abordagem qualitativa não eliminou de sua estrutura ou da própria sistematização dos dados o uso de técnicas de tratamento de cunho quantitativo. Para Demo (1998) apud Ramires e Pessôa (2013, p. 25), sendo as pesquisas qualitativas e quantitativas complementares, no máximo, uma dessas pode ser priorizada em detrimento da outra. Como será possível observar no subtítulo que trata dos impactos 
socioeconômicos no Norte Fluminense, a utilização de dados secundários quantitativos sobre o objeto de estudo se mostrou essencial para a compreensão do campo.

\section{Os impactos da indústria do petróleo e o debate sobre justiça ambiental}

Ainda que o termo impacto demonstre ser polivalente, sua melhor compreensão se dá quando considerado o contexto de sua aplicação. Nas Ciências Humanas, o seu uso está associado ao resultado de uma ação que, geralmente, tem potencial para alterar um quadro posto, como na alteração de uma determinada condição ou situação por meio da atividade humana. Nessa perspectiva, toma-se o uso do termo impacto como referência às consequências da atividade petrolífera, e por isso, toda a discussão sobre esse termo será tratada à luz da literatura sobre os impactos da indústria do petróleo.

Franks (2012, p. 3-4), ao ampliar o debate sobre a relação entre as atividades de exploração de recursos naturais - que engloba a atividade petrolífera e seus impactos sociais - ressalta a necessidade de se adotarem mecanismos de participação social para potencializar os impactos positivos, assim como a adoção de medidas de mitigação para os impactos negativos. Essa análise ganha relevância no debate sobre a conveniência de garantir a gestão responsável e integrada quanto às demandas econômicas, sociais e ambientais, criando canais de diálogo entre comunidade, empresas e governos.

Já Mota et al (2007, p. 290) entende que o termo "impacto" remete a algo vivido ou sentido, por um indivíduo ou grupo social, a partir das consequências da atividade econômica, que podem ser positivas ou negativas. Em geral, os impactos positivos são restritos a uma pequena parcela da população e enfatizam os ganhos econômicos; enquanto os impactos negativos apresentam perdas econômicas e distribuição desigual, que afetam os setores sociais e ambientais mais vulneráveis.

Retomando a perspectiva dos impactos da indústria do petróleo como "possibilidades", Franks (2012, p. 4) cita a ampliação dos ganhos financeiros, o desenvolvimento das capacidades locais, a melhoria da infraestrutura local e a implementação de programas ambientais e sociais. Exemplificando essa condição, toma-se como referência Serra (2007, p. 
78) que discorre sobre o determinismo geográfico e as regras de rateio das rendas petrolíferas que, acabam por beneficiar os estados e municípios que abarcam as regiões produtoras de petróleo. Para os municípios do Norte Fluminense inseridos na zona de produção primária da Bacia de Campos foi cunhada a expressão "municípios petrorentistas" como forma de reafirmar a condição de recebedores das vultosas rendas petrolíferas, ainda que a maioria deles não abriguem, efetivamente, instalações industriais do setor (Serra; Terra; Pontes, 2006, p. 65).

Para ilustrar uma das faces possíveis do impacto negativo, foi trazido à baila o quadro de "Doença Holandesa" identificado em algumas economias dependentes das rendas petrolíferas. Esse quadro trata do processo de desestruturação da economia holandesa na década 1960, quando ganhou corpo a atividade de E\&P de petróleo e gás natural no país (SOUZA JUNIOR, 2008). A dependência econômica por essas rendas reflete um dos piores impactos da atividade petrolífera, uma vez que a condição finita do petróleo, assim como a possibilidade de mudança das regras de distribuição das rendas petrolíferas, ou ainda, as crises econômicas e políticas, como a que se vive neste momento, podem desestruturar as finanças dos entes federados que dependem dessas rendas.

No esforço de compreender o impacto da indústria do petróleo por esse prisma, Lemos e Neves (2011) propuseram analisar o setor agropecuário do município petrorentista de Quissamã à luz do paradigma da Doença Holandesa, demonstrando a relação entre a queda da produção agropecuária e o crescimento do recebimento das rendas petrolíferas. A partir desse quadro, evidenciou-se o crescimento da máquina pública e a oferta de oportunidades de trabalho no setor petrolífero em consonância com o declínio da produção e do emprego agropecuário na cidade, tornando a econômica local ainda mais dependente dos royalties e participações especiais do petróleo.

Uma questão importante nessa discussão está relacionada com a capacidade que cada realidade impactada pela indústria petrolífera tem de "aproveitar" as possibilidades dessa condição. Franks (2012, p. 4-5) analisa a criação dos novos empregos na indústria petrolífera que, em geral, exige mão de obra qualificada. Essa condição pode ser entendida como um impacto positivo. Entretanto, caso a população local não apresente a qualificação técnica requisitada, não conseguirá acessar esses empregos. Em outras palavras, um impacto que seria positivo acaba se tornando negativo, pois a população local não se beneficiará das 
novas oportunidades de emprego, enquanto observará a elevação do custo de vida e o acirramento na disputa por postos de trabalho.

Retratando o exemplo citado no parágrafo anterior, Piquet (2012, p. 57) classifica os impactos da indústria em dois tipos principais: o recebimento das rendas petrolíferas e a instalação efetiva de indústrias ligadas ao setor no território de um determinado ente federado. Nos municípios do Norte Fluminense que se localizam geograficamente na área da Bacia de Campos, considerando os impactos da indústria do petróleo a partir da divisão de tipos propostos por Piquet constatou-se que, apenas, Macaé recebeu em seu território a instalação de indústrias voltadas para a atividade petrolífera, enquanto nos demais municípios predominou o impacto correspondente ao recebimento das rendas petrolíferas (Serra; Terra; Pontes, 2006, p. 66).

O Relatório Final do Diagnóstico Participativo do "Programa de Educação Ambiental da Bacia de Campos (PEA-BC)" estabeleceu cinco macroimpactos socioeconômicos relacionados à indústria do petróleo: i) ocupação do espaço marinho; ii) dinâmica demográfica; iii) ocupação e uso do solo; iv) pressão sobre a infraestrutura urbana, social e de serviços; v) royalties. As categorias foram definidas considerando "as características operacionais da indústria do petróleo e gás na Bacia de Campos associadas a uma análise dos diagnósticos realizados para os Estudos de Impacto Ambiental - EIA" (PETROBRAS, 2012, p. 551).

Nessa última definição de impacto da indústria do petróleo, foi possível identificar as diversas consequências que essa indústria pode proporcionar nas áreas onde se estabeleceram suas atividades. Isso demonstrou que, apesar do recebimento dos royalties e participações especiais ser o mais evidente impacto da atividade petrolífera na região, esse não é o único. Franks (2012, p. 4-5) ressalta a importância da relação entre empresas que atuam na atividade de E\&P de petróleo, governos que são os "beneficiários" das rendas petrolíferas e a comunidade para a implementação de espaços públicos, onde as demandas dos diferentes entes são colocadas em pauta, permitindo a potencialização dos impactos positivos e a mitigação dos impactos negativos.

Um dos impactos abordados pelo Relatório do PEA-BC (reforçado pelos dados da evolução demográfica) está na problemática da expansão urbana desordenada, resultando em 
conflitos locacionais relacionados aos efeitos da aglomeração sem planejamento, a falta de infraestrutura e a priorização pelo poder público de poucas e seletivas áreas em detrimento de outras partes da cidade. Nesse cenário, emergiu o debate sobre a justiça ambiental nos espaços urbanos ${ }^{38}$, a partir do reconhecimento de como os riscos ambientais afetaram de forma desigual e diferente a parcela da população mais vulnerável socioeconomicamente, que tendia a receber de forma mais acentuada os impactos da expansão urbana. Essa concepção se afastou de uma visão de justiça como direito individual e privilegiou a ação pautada na solidariedade e coletividade entre os afetados (Barros; Silva, 2012, p. 17).

Acselrad (2010, p. 108), tomando como base as ações do Movimento de Justiça Ambiental dos Estados Unidos, demonstra que a noção de justiça ambiental ressignificou a questão ambiental, em que as demandas sociopolíticas diretamente envolvidas com a conotação de justiça social passaram a integrar esse debate. Diretamente relacionado à construção de novas arenas de disputa da sociedade, os diferentes agentes que a compõem buscam construir o diálogo para a solução de suas demandas em uma relação que, na maioria das vezes, não é harmônica. É justamente nesses espaços que a questão ambiental mostra seu caráter de luta por justiça social, incluindo em sua pauta reivindicações de questões sociais.

No Brasil, a agenda da justiça ambiental recebeu forte influência do movimento norteamericano. A Conferência das Nações Unidas sobre o Meio Ambiente e o Desenvolvimento realizada na cidade do Rio de Janeiro, em 3-14/06/1992, também referida como "Rio92", é reconhecida como o marco na implementação dessa discussão no país. Outro evento importante para o movimento por justiça ambiental ocorreu no ano de 2001, com a criação da Rede Brasileira de Justiça Ambiental. Entretanto, Herculano (2002, p. 144) pondera que, mesmo sem utilizar o termo propriamente dito, a luta por justiça ambiental já vem acontecendo no Brasil antes desses marcos, através de movimentos sociais que combatem

\footnotetext{
${ }^{38}$ O debate acerca da justiça ambiental surgiu nos Estados Unidos na década de 1980, a partir de discussões que já vinham se desenvolvendo desde a década anterior, por meio da ação conjunta de diferentes setores da sociedade os quais questionavam as condições inadequadas de vida a que grupos mais vulneráveis socioeconomicamente eram condicionados. Esse período foi marcado pela construção desse debate, que chegou a influenciar a agenda ambientalista. A condição socioeconômica desses grupos da sociedade refletia diretamente a estratificação social dos Estados Unidos à época: "áreas de concentração de minorias raciais têm uma probabilidade desproporcionalmente maior de sofrer com os riscos e acidentes ambientais (ACSELRAD; MELLO; BEZERRA, 2009, p. 16).
} 
as injustiças ambientais e que questionam os efeitos negativos do que se entende como "custos do desenvolvimento".

Ainda que exista no imaginário de muitos a diferenciação entre o meio ambiente entendido como um ambiente "natural", desconectado da sociedade e da cidade - deve ser destacada a ideia de meio ambiente como um espaço onde os aspectos naturais e sociais convivem e se estruturam mutuamente, ou seja, sem a possibilidade de dissociar um do outro. Assim, a cidade e seus habitantes integram o meio ambiente, já que é o lugar onde bilhões de pessoas vivem e convivem com o próximo e com o mundo, desfrutando os recursos ambientais para a reprodução da própria vida e sofrendo as consequências perversas do mau uso desses (Quintas, 2006, p. 20-21).

O debate sobre justiça ambiental deve ser entendido como um mecanismo de superação dos problemas ambientais, sempre ressaltando que esse "ambiente" deve ser considerado em seus múltiplos aspectos: físico, social, econômico, político e cultural. Por meio das reflexões expostas, pode-se inferir que tais direitos e obrigações só serão alcançados com a garantia de condições de exercício da justiça social, ou seja, assegurando a inserção da população socioeconomicamente vulnerável nas arenas e fóruns de debate e desenvolvimento de ações voltadas para a questão ambiental.

Na perspectiva das cidades pequenas petrorentistas do Norte Fluminense essa condição tem relação direta com práticas de controle social relacionadas à destinação das rendas petrolíferas. Assim, é trazida à baila a caracterização socioeconômica de Carapebus e de Quissamã, municípios que registraram relevante crescimento demográfico nos últimos dezoito anos, sendo superados na mesorregião apenas por Macaé. Em teoria, a condição dupla de disponibilidade orçamentária e incremento populacional estabelece nessas cidades um verdadeiro laboratório no que tange à discussão sobre os impactos da indústria do petróleo, a promoção a justiça ambiental e o processo de expansão urbana.

\section{Evolução dos indicadores socioeconômicos no Norte Fluminense}

Inicialmente, analisou-se o crescimento demográfico dos municípios que compõem o Norte Fluminense entre o período de 2000 a 2018. É importante destacar que o período analisado 
levou em consideração o primeiro censo demográfico realizado após a promulgação e regulamentação da chamada "Lei do Petróleo" (9.478/1997), que ampliou sobremaneira o orçamento público de alguns municípios da mesorregião, e a projeção populacional divulgada pelo IBGE para o ano de 2018, ano de corte da pesquisa em tela.

O Norte Fluminense apresentou em 2018 uma população de 948.195 habitantes. Deste total, 503.424 habitantes, ou seja, mais da metade do contingente total, estão estabelecidos em Campos dos Goytacazes, tradicional núcleo regional. Em seguida vem o município de Macaé, com 251.631 habitantes, cidade que tem crescido em importância no contexto regional e nacional após a instalação da Petrobras em seu território, na década de 1970. Considerando apenas esses dois municípios, concentram sozinhos quase $80 \%$ da população regional. Os outros sete municípios apresentam população de 193.140 habitantes, sendo que em nenhum desses entes federados a população local é superior a 50 mil habitantes. Isso demonstra como a distribuição demográfica na mesorregião é irregular, ocorrendo a concentração populacional nos dois núcleos urbanos de maior relevância econômica e histórica.

Ao analisar de maneira específica os municípios de Carapebus e de Quissamã foi percebido que eles apresentaram o segundo e terceiro maior crescimento populacional da região, ficando atrás somente de Macaé. Em dezesseis anos, a população de Carapebus cresceu 80\% e de Quissamã evoluiu em 72\%. Entretanto, mesmo com tal crescimento demográfico, ambos os municípios ainda figuram como os menos populosos do Norte Fluminense, juntamente com Cardoso Moreira, com 12.519 habitantes, e Conceição de Macabu, com 22.461 habitantes. Ou seja, mesmo com o intenso crescimento populacional vivenciado nos últimos anos, Carapebus e Quissamã ainda seguem como as cidades com os menores contingentes populacionais do Norte Fluminense.

No que tange aos indicadores sociais, tomou-se como análise a evolução do Índice de Desenvolvimento Humano Municipal (IDH-M) ${ }^{39}$. Com o risco de reduzir a questão a dados numéricos, o IDH-M atua como um parâmetro comum a todos os municípios, possibilitando assim análises comparativas que não invalidam o uso desse indicador como fonte de

\footnotetext{
${ }^{39}$ Esse índice foi criado pela Organização das Nações Unidas (ONU) para avaliar o desenvolvimento social e econômicos em escala local. Levou-se em consideração os índices de alfabetização, a renda per capita e a expectativa de vida dos municípios.
} 
informação. Assim, os resultados concernentes a esse indicador permitiram concluir que, mesmo usufruindo da condição de municípios recebedores das rendas petrolíferas, a maior parte dos municípios do Norte Fluminense não conseguiram significativo avanço nos indicadores da saúde, educação e distribuição de renda.

Tabela 1 - Evolução populacional dos municípios do Norte Fluminense (2000-2018)

\begin{tabular}{c|c|c|c|c}
\multirow{2}{*}{ Cidades } & \multicolumn{3}{|c|}{ População } & \multirow{2}{*}{$\begin{array}{c}\text { Variação } \\
\text { (\%) }\end{array}$} \\
\cline { 2 - 4 } & $\mathbf{2 0 0 0}$ & $\mathbf{2 0 1 0}$ & $\mathbf{2 0 1 8}$ & $\mathbf{2 4 \%}$ \\
\hline Campos dos Goytacazes & 407.168 & 463.731 & 503.424 & $85 \%$ \\
\hline Carapebus & 8.666 & 13.359 & 16.039 & $2 \%$ \\
\hline Cardoso Moreira & 12.595 & 12.600 & 12.826 & $23 \%$ \\
\hline Conceição de Macabu & 18.782 & 21.211 & 23.064 & $90 \%$ \\
\hline Macaé & 132.461 & 206.728 & 251.631 & $77 \%$ \\
\hline Quissamã & 13.674 & 20.242 & 24.246 & $2 \%$ \\
\hline São Francisco de Itabapoana & 41.475 & 41.354 & 42.201 & $5 \%$ \\
\hline São João da Barra & 36.789 & 37.543 & 38.626 & $31 \%$ \\
\hline Total & 27.682 & 32.747 & 36.138 & $36 \%$ \\
\hline
\end{tabular}

*População residente estimada.

Fonte: Tabela elaborada pelos autores a partir do IBGE Cidades (2018).

Como evidencia a Tabela 2, foi possível constatar que em 2010 apenas Macaé apresentou índice maior que a média dos demais municípios do Estado do Rio de Janeiro, que é de 0,761. Campos dos Goytacazes, Carapebus, Cardoso Moreira, Conceição de Macabu, Quissamã, São Fidélis, São Francisco de Itabapoana e São João da Barra apresentaram IDHM inferior à média estadual. No intervalo de 2000 a 2010, quando tais municípios passaram a receber de forma mais acentuada as rendas petrolíferas, o IDH-M de Carapebus e de Quissamã apresentou menor evolução que o indicador que São Francisco de Itabapoana (27\%), e no caso de Quissamã (25\%), igual ao de Cardoso Moreira (25\%). Carapebus apresentou evolução de $23 \%$ do seu IDH-M nesse período. É válido destacar que São Francisco de Itabapoana e Cardoso Moreira não estão localizados na zona de produção primária da Bacia de Campos e não apresentam em seu território a instalação de equipamentos de apoio à atividade off-shore, ou seja, não figuram entre os municípios que mais recebem as rendas petrolíferas. 
Apesar do quadro economicamente favorável, principalmente para os municípios inseridos na zona de produção primária, não é possível afirmar que para além do crescimento houve o desenvolvimento econômico na mesma proporção, ou seja, que a população mais vulnerável socioeconomicamente se beneficiou diretamente dessa condição de sobrefinanciamento orçamentário. O IDH-M evoluiu em todos os municípios, repercutindo a melhoria dos indicadores nos níveis estadual e federal, entretanto, a observação de que mesmo com a condição econômica favorável, os índices dos municípios analisados permanecem aquém da média estadual.

Tabela 2 - Evolução do IDH-M dos municípios do Norte Fluminense (1991-2010)

\begin{tabular}{c|c|c|c|c}
\hline Cidade & $\mathbf{1 9 9 1}$ & $\mathbf{2 0 0 0}$ & $\mathbf{2 0 1 0}$ & Variação (\%) \\
\hline São Francisco de Itabapoana & 0,344 & 0,503 & 0,639 & $46 \%$ \\
\hline Carapebus & 0,412 & 0,579 & 0,713 & $42 \%$ \\
\hline Quissamã & 0,406 & 0,561 & 0,704 & $42 \%$ \\
\hline Cardoso Moreira & 0,386 & 0,520 & 0,648 & $40 \%$ \\
\hline São Fidélis & 0,449 & 0,590 & 0,691 & $35 \%$ \\
\hline Conceição de Macabu & 0,483 & 0,615 & 0,712 & $32 \%$ \\
\hline Macaé & 0,534 & 0,665 & 0,764 & $30 \%$ \\
\hline Campos dos Goytacazes & 0,505 & 0,618 & 0,716 & $29 \%$ \\
\hline São João da Barra & 0,484 & 0,548 & 0,671 & $28 \%$ \\
\hline
\end{tabular}

Fonte: Tabela elaborada pelos autores a partir do PNUD - Atlas de Desenvolvimento Humano no Brasil (2018).

$\mathrm{Na}$ análise dos indicadores econômicos, destacaram-se os índices referentes ao recebimento das rendas petrolíferas, item relativo à mais importante fonte de renda de boa parte dos municípios do Norte Fluminense. Entre os anos de 2014 e 2018 houve uma queda de $64 \%$ no valor repassado de royalties e participações especiais para os entes da mesorregião, o que representa uma redução de mais de 1 bilhão e 300 milhões de reais. Se for considerada a média do que foi recebido por esses municípios durante o período de 2000 a 2014, chega-se ao valor de 1 bilhão 361 milhões de reais, que corresponde a uma redução de $42 \%$ em relação ao valor repassado no ano de 2018. Tais valores indicam que, de fato, houve uma forte redução dos valores recebidos das rendas petrolíferas entre 2015 e 2017. Entretanto, não se pode ignorar a oportunidade que os municípios recebedores de vultosas rendas tiveram, e ainda têm, com sobrefinanciamento das suas receitas orçamentárias. 
Mediante o exposto, as análises referentes ao recebimento de royalties e participações especiais utilizarão como marco inicial o ano de 2000, pois foi a partir desse momento que se observou o recebimento de valores mais expressivos das rendas petrolíferas, e 2018 como ano final, período que contemplou os últimos dados obtidos na pesquisa de campo em Carapebus e Quissamã. Os municípios do Norte Fluminense foram privilegiados pelo recebimento das rendas petrolíferas; recebendo a título de compensação financeira pelas atividades de E\&P do petróleo e gás natural, mais de 22 bilhões de reais entre os anos 2000 e 2018. Como já mencionado, isso ocorre devido à metodologia estabelecida pelo IBGE para criar as linhas ortogonais e paralelas que são projetadas a partir do litoral em direção aos poços de extração petrolífera.

Tabela 3 - Dependência orçamentária das rendas petrolíferas nos municípios do Norte Fluminense (2000-2018)

\begin{tabular}{c|c|c}
\hline Cidades & $\begin{array}{c}\text { Dependência orçamentária } \\
\text { das rendas petrolíferas }\end{array}$ & $\begin{array}{c}\text { Média anual receita } \\
\text { rendas petrolíferas (R\$) }\end{array}$ \\
\hline Campos dos Goytacazes & $58 \%$ & $781.681 .164,85$ \\
\hline São João da Barra & $56 \%$ & $128.698 .874,06$ \\
\hline Quissamã & $50 \%$ & $81.948 .553,29$ \\
\hline Carapebus & $48 \%$ & $26.728 .854,04$ \\
\hline Macaé & $38 \%$ & $375.588 .174,10$ \\
\hline Conceição de Macabu & $13 \%$ & $4.357 .539,98$ \\
\hline Cardoso Moreira & $13 \%$ & $3.820 .449,92$ \\
\hline São Fidélis & $11 \%$ & $5.135 .052,58$ \\
\hline São Francisco de Itabapoana & $9 \%$ & $5.291 .300,06$ \\
\hline
\end{tabular}

Fonte: Tabela elaborada pelos autores a partir do Inforoyalties (2018).

Quissamã e Carapebus são, respectivamente, o terceiro e quarto municípios mais dependentes das rendas petrolíferas, atrás de Campos dos Goytacazes e São João da Barra. Seguem como dependentes das rendas petrolíferas, em ordem decrescente, os municípios de Macaé, Conceição de Macabu, Cardoso Moreira, São Fidélis e São Francisco de Itabapoana. Já no que diz respeito ao recebimento das rendas petrolíferas acumuladas nesse período, Campos dos Goytacazes figura na primeira posição, com mais de 13 bilhões de reais, muito distante de Macaé, com mais de 5 bilhões de reais. Quissamã e Carapebus são, respectivamente, quarto e quinto municípios que mais receberam as rendas 
petrolíferas, sendo que Quissamã recebeu valor quatro vezes maior que Carapebus em igual período.

É válido ressaltar que Campos dos Goytacazes, Carapebus, Macaé, Quissamã e São João da Barra, municípios litorâneos da região, estão localizados na zona de produção primária de petróleo da Bacia de Campos e, por esse motivo, recebem valores maiores das rendas petrolíferas, diferente dos demais municípios da região, que se localizam na zona de produção secundária, a exceção é o município de São Francisco de Itabapoana, que mesmo sendo um município litorâneo, não está inserido na zona de produção primária.

Tal condição reflete uma das piores consequências da atividade petrolífera, uma vez que fatores como a condição finita desse recurso mineral, ou a mudança das regras de distribuição das rendas petrolíferas e ainda a queda do preço do petróleo podem influenciar diretamente no valor recebido pelos municípios produtores de petróleo, criando uma condição de dificuldade econômica como a que foi possível observar durante a recente queda no preço do barril do petróleo e as dificuldades enfrentadas por municípios e estados petrorentistas.

Outro indicador que auxilia na compreensão da importância das rendas petrolíferas para os municípios é a relação entre a receita orçamentária e o quantitativo populacional. Assim, a Tabela 4 demonstra como as rendas petrolíferas, que compõem boa parte da receita orçamentária desses entes federados, afetaram proporcionalmente a capacidade orçamentária municipal a partir da observação da "receita per capita".

Tabela 4 - Relação receita orçamentária x população x receita per capita dos municípios do Norte Fluminense (2018)

\begin{tabular}{c|ccc}
\hline Cidade & Receita orçamentária (R\$) & População* & Per capita (R\$) \\
\hline Campos dos Goytacazes & $1.625 .032 .365,14$ & 503.424 & $3.227,95$ \\
\hline Carapebus & $78.501 .259,89$ & 16.039 & $4.894,39$ \\
\hline Cardoso Moreira & $62.394 .541,79$ & 12.826 & $4.864,69$ \\
\hline Conceição de Macabu & $71.282 .338,46$ & 23.064 & $3.090,63$ \\
\hline Macaé & $2.071 .238 .054,82$ & 251.631 & $8.231,25$ \\
\hline Quissamã & $187.888 .104,36$ & 24.246 & $7.749,24$ \\
\hline São Fidélis & $92.183 .175,75$ & 38.626 & $2.386,55$ \\
\hline São Francisco de Itabapoana & $135.313 .625,70$ & 42.201 & $3.206,40$ \\
\hline São João da Barra & $269.162 .363,22$ & 36.138 & $7.448,18$ \\
\hline
\end{tabular}

*População residente estimada.

Fonte: Tabela elaborada pelos autores a partir do Inforoyalties e IBGE Cidades (2018). 
Considerando essa relação, Quissamã apresenta a segunda receita per capita do Norte Fluminense, reforçando sua condição privilegiada. Os demais municípios petrorentistas também se destacam, estando Macaé em primeiro lugar e Carapebus em quarto lugar na relação de maiores receitas orçamentárias per capita do Norte Fluminense. Quando comparado tal indicador à média dos municípios do estado do Rio de Janeiro, que é de $\mathrm{R} \$$ 3.223,43, observou-se que, apenas, Conceição de Macabu, São Fidélis e São Francisco de Itabapoana estão abaixo da média estadual. É importante relembrar que esses últimos municípios não estão inseridos na zona primária de produção do petróleo da Bacia de Campos.

Diferente da maioria dos municípios brasileiros, que apresentam restrições orçamentárias para aplicação de políticas públicas, Carapebus e Quissamã dispõem de situação econômica favorável devido ao recebimento de royalties e participações especiais. Ao menos em tese, um sobrefinanciamento orçamentário possibilitaria a implantação de políticas públicas visando ao atendimento das demandas da sociedade. Nesse contexto, destacou-se que nem sempre há compatibilidade entre as intervenções e declarações de vontade e as ações desenvolvidas. Devem ser consideradas também as "não ações", as omissões, como formas de escolhas políticas, pois representam opções e orientações dos que ocupam cargos. Evidentemente que com mais recursos financeiros, a necessidade de controle e fiscalização na aplicação de tais recursos devem ser ampliadas, incluindo o fomento à participação popular.

Reiterando a condição dos municípios como petrorentistas, é fundamental a participação da sociedade, pois a contribuição que poderia fornecer, sem dúvidas, ampliaria o potencial de atuação do poder público frente aos impactos da indústria do petróleo nessas localidades. No subtítulo a seguir, propôs-se analisar a evolução da expansão urbana nessas cidades utilizando mapas e imagens. Assim, pretendeu-se localizar, espacialmente, a realidade identificada na exploração do campo e nas entrevistas realizadas, reconhecendo as ações de ordenamento urbano implementadas (ou não) em Carapebus e Quissamã. Nesse contexto, buscou-se compreender os aspectos de promoção de justiça ambiental, destacando as semelhanças e diferenças entre ambas as realidades. 


\section{Realidade socioespacial de Carapebus e Quissamã}

A partir dos dados coletados na exploração do campo e nas entrevistas, foi possível relacionar aquilo que pode ser entendido como condição de degradação ambiental com à realidade observada nos novos eixos de expansão urbana de Carapebus e de Quissamã. Essa questão será analisada, evidenciando os problemas urbanos, os contrastes e as situações de injustiça ambiental. Como forma de melhor compreensão, serão utilizados como instrumento de apoio as análises a descrição e a catalogação dos equipamentos urbanos identificados na exploração do campo.

Já a abordagem em ambos os municípios dar-se-á de forma concomitante, buscando facilitar a identificação das semelhanças e diferenças de cada realidade. Sem que se perca a visão de injustiça ambiental como exposição desigual aos riscos ambientais, em especial, da parcela mais vulnerável da população, retoma-se a definição de justiça ambiental discutida por Bullard (1994) apud Acselrad, Mello e Bezerra (2009):

\footnotetext{
"É a condição de existência social configurada através do tratamento justo e do envolvimento significativo de todas as pessoas, independente de sua raça, cor ou renda no que diz respeito à elaboração, desenvolvimento, implementação e aplicação de políticas, leis e regulações ambientais. Por tratamento justo, entenda-se que nenhum grupo de pessoas, incluindo-se aí grupos étnicos, raciais ou de classe, deva suportar uma parcela desproporcional das consequências ambientais negativas resultantes da operação de empreendimentos industriais, comerciais e municipais, da execução de políticas e programas federais, estaduais ou municipais, bem como das consequências resultantes da ausência ou omissão destas políticas" (Bullard, 1994 apud Acselrad; Mello; Bezerra, 2009, p. 16).
}

Inicialmente, buscou-se reconhecer os impactos considerados diretos e localizados tanto nas sedes municipais, ou seja, nas cidades, quanto no restante do território municipal. Como já exposto anteriormente nas discussões de Serra, Terra e Pontes (2006) e Piquet (2012) e confirmado nas entrevistas e observações in loco realizadas, não existem indústrias do setor petrolífero efetivamente instaladas nos municípios, apesar da política de atração 
de indústrias praticadas por meio da implementação das Zonas Especiais de Negócios (ZEN) em cada localidade.

Localizada às margens da Rodovia Mário Covas (BR-101 Norte), a ZEN de Carapebus apresenta três unidades fabris, sendo que apenas uma está em funcionamento. Trata-se de um galpão para contêineres, pertencente à empresa que atua no ramo de transporte e logística e que presta serviços de apoio às atividades de off-shore da indústria do petróleo. Já na sede municipal, o principal impacto direto da indústria do petróleo são os dutos da Petrobras Transporte S.A. (Transpetro), que fazem o transporte de parte do petróleo e gás natural extraído da Bacia de Campos em direção às refinarias de Cabiúnas, em Macaé, e REDUC, no município de Duque de Caxias.

Já em Quissamã, é possível reconhecer como principais impactos diretos da indústria do petróleo o Complexo Portuário de Barra do Furado e de Farol de São Tomé, atualmente com obras paralisadas e localizado a $40 \mathrm{~km}$ da sede municipal, e os dutos da Transpetro que cortam a mancha urbana da sede municipal entre os bairros de Caxias e da Ribeira. Apesar de contar com uma ZEN, localizada a $16 \mathrm{~km}$ do centro da cidade, não há registros da instalação de empresas relacionadas ao setor petrolífero nesse empreendimento.

Os dutos da Transpetro atravessam as sedes municipais de Carapebus e de Quissamã, estabelecendo uma ruptura na continuidade da mancha urbana em tais cidades. As informações obtidas pelos moradores demonstram que ocorreram desapropriações de residências tanto na implementação, quanto nas intervenções de ampliação das faixas de dutos. O que chama a atenção nessa ruptura da mancha urbana é a ausência aparente de maiores intervenções públicas no perímetro "desconectado" do restante da cidade.

No caso de Carapebus, foi possível identificar que muitas ruas não contam com pavimentação e algumas residências não apresentam serviços de água e esgoto. Em Quissamã, o bairro da Ribeira apresenta toda a sua área territorial separada da cidade, mas conta com todas as ruas pavimentadas e a oferta de saneamento básico. Ressalta-se a existência de uma pista de contenção criada pelo poder público local para limitar o crescimento do bairro em direção à Lagoa da Ribeira. Nos dois casos em análise, foi possível 
observar a ausência de equipamentos urbanos instalados nas áreas para além da passagem dos dutos da Transpetro.

Ao analisar o que se considera como impactos "indiretos", especialmente aqueles relacionados ao crescimento urbano dessas cidades, procurou-se fazer um panorama geral para em seguida avançar para a análise de casos de maior representatividade nessas realidades. Tanto em Carapebus quanto em Quissamã foram identificadas áreas ocupadas irregularmente, concentração de submoradias, diversas ruas e calçadas com pavimentação e/ou piso irregular (ou sua ausência por completo), deficiências no sistema de transporte público, no recolhimento de lixo, na oferta de água e no recolhimento e tratamento de esgoto, despejo de dejetos em rios e lagoas e precariedade ou limitação na oferta de equipamentos urbanos.

Em Carapebus, houve maior número de áreas reconhecidas como de expansão recente, ou seja, maior fragmentação das novas áreas urbanizadas na sede municipal. Em geral, as novas áreas apresentam déficit de infraestrutura urbana, como foi possível registrar nas visitas ao campo. O único serviço público oferecido em todos os novos eixos de expansão urbana é a coleta regular de lixo. Já nos bairros de Barreiros, Loteamento APCC, São Domingos e Ubás, não há a oferta de fornecimento de água e recolhimento de esgoto. Também foi possível constatar a ausência parcial, e em alguns bairros total, de pavimentação e passeios públicos, assim como a concentração da oferta dos equipamentos urbanos, no centro da cidade. Com exceção dos bairros de Caxanga e Oscar Brito, os demais são bairros distantes do centro, ainda assim, não há oferta de linhas regulares de transporte público. A Figura 3 demonstra a evolução dos novos eixos de expansão urbana em Carapebus.

Tomando como referência os bairros mais populosos da cidade para além do centro, foram abordadas as condições ambientais disponíveis em Caxanga e Ubás. O primeiro bairro se subdivide em Caxanga Baixa e Alta, sendo reconhecido pela população local como uma área em processo de favelização. A partir da observação visual das edificações, foi possível identificar que o padrão econômico dos seus moradores não é elevado, devido a maioria das edificações apresentarem aparentemente condições inacabadas, muitas construídas 
dimensões pequenas, gerando um maior adensamento populacional, inclusive com pontos de verticalização. O Secretário de Planejamento Urbano de Carapebus citou essa condição do bairro de Caxanga, assim como os munícipes entrevistados, salientando casos de violência relacionados ao tráfico de drogas existente no bairro.

Em Caxanga Baixa, também observou-se a ocupação de áreas próximas dos cursos hídricos que compõem a Lagoa de Carapebus, parte integrante do Parque Nacional da Restinga de Jurubatiba. De conhecimento dos munícipes, essas áreas ocupadas são passíveis de alagamento, como já ocorrido em anos anteriores, com um complicador: o esgoto coletado na região central de Carapebus é despejado nesse curso hídrico, sem o tratamento adequado, como alertado pelo Secretário de Planejamento Urbano e denunciado pelos munícipes entrevistados.

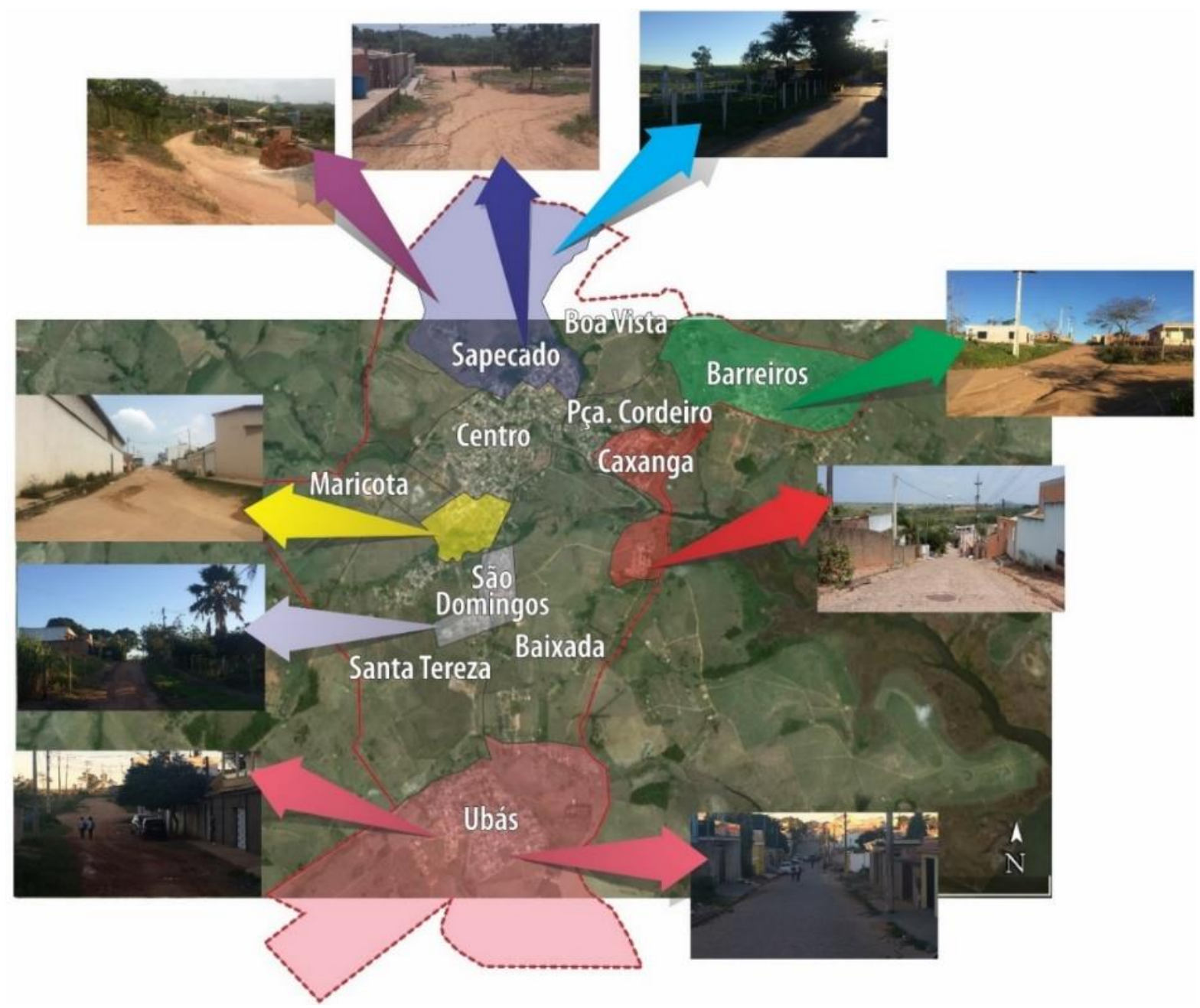

Fig. 3 - Novos eixos de expansão urbana em Carapebus

Fonte: Mapa elaborado pelos autores a partir do Google, exploração do campo e entrevistas (2016) 
Tabela 5 - Estrutura urbana novos eixos de expansão - Carapebus

\begin{tabular}{|c|c|c|c|c|c|}
\hline \multicolumn{6}{|c|}{ ESTRUTURA URBANA NOVOS EIXOS DE EXPANSÃO - CARAPEBUS } \\
\hline Bairro & Água encanada & Rede de esgoto & Coleta de lixo & Pavimentação & Equipamento público \\
\hline Barreiros & Não & Não & Sim & Não & \\
\hline Caxanga & Sim & Sim & Sim & Parcial & $\begin{array}{c}\text { Praça/Escola } \\
\text { Municipa//Posto de Saúde }\end{array}$ \\
\hline Loteamento APC ${ }^{*}$ & Nāo & Não & Sim & Não & \\
\hline Oscar Brito & Sim & Sim & Sim & Parcial & \\
\hline Sapecado & Sim & Sim & Sim & Parcial & \\
\hline São Domingos* & Não & Não & Sim & Parcial & \\
\hline Ubás & Nāo & Não & Sim & Não & $\begin{array}{l}\text { Praça/Escola } \\
\text { Municipal/Posto de Saúde }\end{array}$ \\
\hline
\end{tabular}

Fonte: Tabela elaborada pelos autores a partir da exploração do campo e entrevistas (2016).

O bairro de Ubás, que apresenta população em torno de 3 mil habitantes, é o mais longe do centro da cidade, distante $3 \mathrm{~km}$. Dispõe de toda a estrutura física para o fornecimento dos serviços de água e esgoto já instalados, porém, tal serviço não ocorre de maneira regular. Como forma de acessarem esses serviços, os moradores da localidade recorrem ao uso de poços artesianos para a captação de água e fossas sépticas para a destinação do esgoto doméstico.

Emancipado seis anos antes, Quissamã é um município com contingente populacional superior a 8 mil habitantes e com uma maior receita orçamentária per capita do que Carapebus. Ali foi possível observar que os novos eixos de expansão urbana estão mais concentrados, seguindo um padrão de crescimento em forma de loteamentos. No geral, as novas áreas apresentam infraestrutura urbana implementada, como registrado na exploração de campo. Todos os bairros reconhecidos apresentaram a oferta de serviços de recolhimento de lixo. Em algumas ruas do bairro Mathias e Sítio Quissamã, não há pavimentação e calçadas, nem fornecimento de água e serviço de esgoto. Já nos demais bairros, foi registrada a disponibilidade desses melhoramentos urbanos.

A dispersão dos equipamentos urbanos em Quissamã, inclusive em bairros identificados como de expansão urbana recente contribui para a não aglomeração desses em uma determinada área, geralmente a central. O centro do município ainda mantém sua hegemonia na oferta de serviços e na disponibilidade de equipamentos urbanos, com destaque para as atividades comerciais estabelecidas na chamada "Rua do Comércio", a presença da sede da Prefeitura Municipal, bancos, correios, igreja matriz, praça central, posto de combustível, entre outros equipamentos. 
No bairro de Alto Alegre, localiza-se o Parque Aquático Municipal, que conta ainda com escola municipal e o Centro Municipal de Especialidade Médica. No bairro de Caxias, foi possível identificar praça de recreação, escola municipal, posto de saúde, além da rodoviária municipal. Por sua vez, no bairro do Sítio Quissamã, identificou-se a disponibilidade de escola municipal e do conselho tutelar. No bairro do Mato de Pipa está instalado o Hospital Municipal e no bairro Mathias estão uma praça com quadra esportiva e um posto de saúde. Apenas no bairro Ribeira, área desconectada do restante da mancha urbana pelos dutos da Transpetro, não se registrou nenhum equipamento urbano instalado.

Nos bairros de Caxias e Sítio Quissamã, como também foi citado pelos munícipes entrevistados e pelo gestor público, foi possível reconhecer um maior adensamento populacional, com novas edificações construídas em lotes já ocupados. Em Caxias, já se observam alguns pontos onde esse processo ocorre de maneira vertical. No Sítio Quissamã, algumas unidades habitacionais construídas pela Empresa Pública Municipal de Habitações de Quissamã apresentam alterações na sua configuração original, com mudanças na sua estrutura. Esses bairros, também, foram apontados como os mais violentos da cidade, com o registro de ações de grupos ligados ao tráfico de drogas. A Figura 4 demonstra a evolução dos novos eixos de expansão urbana em Quissamã.

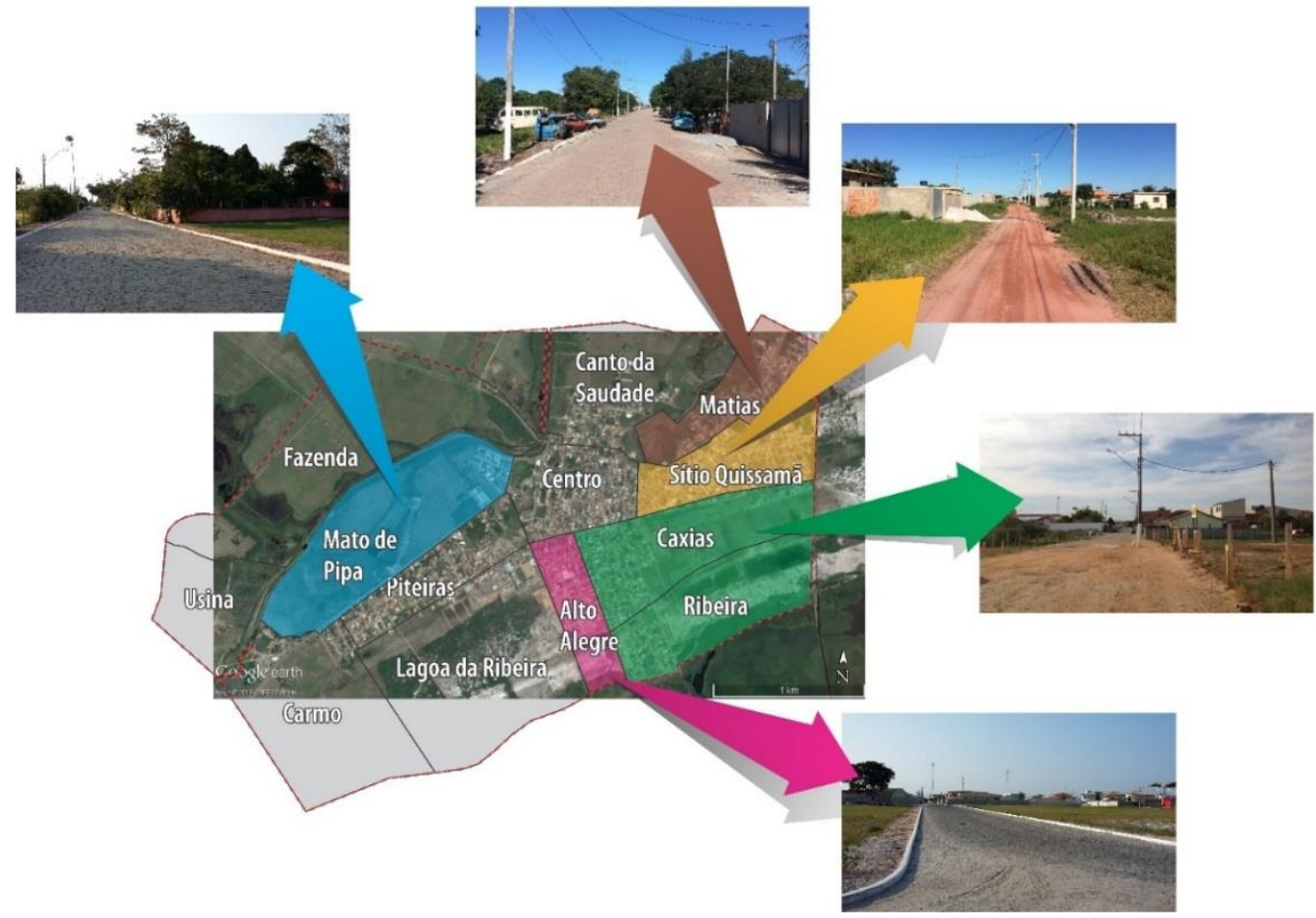

Fig. 4 - Novos eixos de expansão urbana em Quissamã

Fonte: Mapa elaborado pelos autores a partir do Google, Exploração do campo e entrevistas (2016). 
Tabela 6 - Estrutura urbana novos eixos de expansão - Quissamã

\begin{tabular}{|c|c|c|c|c|c|}
\hline \multicolumn{6}{|c|}{ ESTRUTURA URBANA NOVOS EIXOS DE EXPANSÃO - QUISSAMÃ } \\
\hline Bairro & Água encanada & Rede de esgoto & Coleta de lixo & Pavimentação & Equipamento público \\
\hline Alto Alegre (Vista Alegre) & Sim & Sim & Sim & Sim & $\begin{array}{l}\text { Parque Aquático Municipal/ } \\
\text { Escola Municipal/Posto de Saúde }\end{array}$ \\
\hline Caxias & Sim & Sim & Sim & Sim & $\begin{array}{c}\text { Praça/Escola } \\
\text { Municipal/Posto de Saúde }\end{array}$ \\
\hline Mathias & Sim & Sim & Sim & Parcial & Praça/Posto de Saúde \\
\hline Ribeira & Sim & Sim & Sim & Sim & \\
\hline Sítio Quissamã & Sim & Sim & Sim & Parcial & Escola/Conselho Tutelar \\
\hline $\begin{array}{l}\text { Mato de Pipa } \\
\text { (Vivendas do Canal) }\end{array}$ & Sim & Sim & Sim & Sim & Praça \\
\hline
\end{tabular}

Fonte: Tabela elaborada pelos autores a partir da exploração do campo e entrevistas (2016).

Em ambas as cidades, há o entendimento tanto por parte dos munícipes quanto nos dados coletados na exploração de campo de que Quissamã apresenta melhor estruturação do seu espaço urbano. Entretanto, predomina a percepção de que as rendas petrolíferas são importantes para a atuação do poder público local e que, apesar da disponibilidade de tais rendas, a implementação de ações direcionadas à expansão urbana dessas cidades não correspondeu à demanda posta. O papel do Estado, na perspectiva do governo local, estabelece tanto a diferenciação do espaço urbano com áreas providas de serviços e equipamentos urbanos, em detrimento de outras, desprovidas total ou parcialmente destes. Ainda sobre o papel do Estado na promoção da condição de injustiça ambiental no espaço urbano, é reconhecida no poder público municipal a responsabilidade pelas políticas públicas de desenvolvimento urbano, promovendo as intervenções necessárias na oferta da infraestrutura básica aos munícipes. Na ausência de ações nesse sentido, a precarização do espaço urbano é o resultado, também sendo percebido como degradação ambiental. A emergência pela justiça ambiental nos espaços urbanos está relacionada, em sua maioria, à problemática da urbanização, resultando em conflitos locacionais relacionados aos efeitos da aglomeração sem planejamento, à falta de infraestrutura e à priorização pelo poder público de poucas e seletivas áreas, em detrimento da maior parte da cidade, relegada a toda sorte de riscos ambientais.

Nesse aspecto, foi possível identificar como as áreas não centrais ou periféricas (mesmo que esse conceito apresente resistências quanto seu uso em cidades de pequeno porte), são constantemente marginalizadas pelo poder público com a ausência ou deficiência na oferta 
de bens e serviços, alguns de primeira necessidade, como a oferta irregular do fornecimento de água e o recolhimento e tratamento adequado do esgoto. Fica evidente que a simples disponibilidade orçamentária não representa a adequada oferta dos serviços e equipamentos urbanos indispensáveis. Em graus distintos, a condição de injustiça ambiental é identificada na configuração urbana de Carapebus e de Quissamã, pobres cidades ricas produtoras de petróleo do Norte Fluminense.

\section{Considerações}

Este artigo buscou trazer reflexões acerca do debate sobre justiça ambiental nas cidades pequenas do Norte Fluminense impactadas pela indústria do petróleo. O fato de serem cidades pequenas não significa que os impactos da atividade petrolífera foram menos relevantes. Tomou-se como referência a análise de Franks (2012) sobre a condição desses impactos como positivos e negativos e a perspectiva de Piquet (2012) sobre impactos diretos e indiretos da indústria petrolífera. Quanto aos impactos diretos e indiretos, pouco se observou nessas cidades como impacto direto. Nas sedes municipais o que prevalece é a presença de dutos da Transpetro, que estabelecem uma ruptura na mancha urbana e limitam a expansão urbana para essas áreas. É válido destacar a condição dos bairros que foram separados da área central, que em Quissamã e, especialmente, em Carapebus, apresentam características precárias, com a reduzida ação do poder público local na oferta de seus serviços e intervenções.

Já no que tange os impactos indiretos, assim como os demais municípios inseridos na zona de produção primária da Bacia de Campos, o mais relevante impacto vivenciado por Carapebus e Quissamã foi o recebimento das vultosas rendas petrolíferas. Tais rendas são reconhecidas por si só como impactos positivos para esses municípios. Como pôde ser observado nos dados sobre o recebimento dessas rendas, a capacidade orçamentária que o poder público local passou a dispor a partir da regulamentação da chamada Lei do Petróleo proporciona condições econômicas favoráveis para a implementação de políticas públicas nas diversas frentes. 
Porém, os impactos negativos já se tornam evidentes na própria relação desses municípios com o recebimento de royalties e participações especiais. A dependência orçamentária às rendas petrolíferas demonstra que pouco se fez para dinamizar as fontes de rendas pelo poder público local. Não sendo uma característica única de Carapebus e de Quissamã, extensiva às cidades pequenas em geral, a economia local é dependente das ações do poder público local, porém dependentes dos repasses e transferências do Governo Federal por meio do "Fundo de Participação dos Municípios - FPM" (Santos, 2017), repercutindo para a municipalidade as consequências dessa dependência orçamentária.

Outro impacto negativo evidente está na expansão urbana desordenada dessas cidades. No período que compreende o início dos anos 2000 até 2018, a população de Carapebus e de Quissamã cresceu em mais de 77\%. Esse feito só foi superado por Macaé, que apresentou um crescimento populacional maior. A partir das informações expostas, foi possível identificar os impactos indiretos na maior pressão à infraestrutura urbana decorrentes desse crescimento demográfico, que demonstram, de alguma forma, que as rendas petrolíferas estão sendo aplicadas de maneira deficitária nesse contexto. Problemas relacionados com a ocupação de áreas irregulares, submoradias, oferta dos serviços de água e esgoto, pavimentação, transporte e distribuição dos equipamentos urbanos foram encontrados, destoando sobremaneira da condição orçamentária favorável dos municípios em análise.

Lançando mão do debate acerca da justiça ambiental, Acselrad (2009), ao abordar essa questão no Brasil, relaciona a exposição das condições degradantes ambientalmente ao público mais vulnerável socioeconomicamente. Foi possível reconhecer condições de injustiça ambiental em ambas as cidades, reverberando em condições socioespaciais inadequadas, principalmente nos bairros desses novos eixos de expansão urbanas que concentram as moradias ou edificações com piores condições estruturas, podendo deduzir o menor padrão socioeconômicos dos seus moradores. No contraste entre os novos eixos de expansão e a área central das cidades, evidenciou-se o que se entende por periferização.

Sem esgotar o assunto, espera-se que as informações e reflexões expostas nesse artigo possam contribuir com o debate sobre os impactos da indústria do petróleo nas cidades pequenas os quais, como observado, carecem de estudos e iniciativas que busquem ampliar 
sobrefinanciamento orçamentário do poder público local.

\section{Referências}

ACSELRAD, H. Ambientalização das lutas sociais: o caso do movimento por justiça ambiental. Revista Estudos Avançados. São Paulo, vol. 24 no. 68, 2010.

ACSELRAD, H.; MELLO; C.; BEZERRA, G. O que é justiça ambiental. Rio de Janeiro: Ed. Garamond, 2009.

ANP - Agência Nacional do Petróleo. Boletim da Produção de Petróleo e Gás Natural. Junho 2018. Disponível em: http://www.anp.gov.br/?dw=6970. Acesso em agosto de 2018.

BARROS, J.; SILVA, E. Juventude na cidade e justiça ambiental: que papo é esse? Rio de Janeiro: Fase, 2012.

CEPERJ - Centro Estadual de Estatística, Pesquisas e Formação de Servidores Públicos do Estado do Rio de Janeiro. Mapas do Estado do Rio de Janeiro. Dezembro de 2015. Disponível em: http://www.ceperj.rj.gov.br/ceep/pib/pib.html. Acesso em agosto de 2018.

CORRÊA, R. L. O espaço urbano. 4a ed. São Paulo: Editora Ática, 1989.

CRUZ, José Luiz Vianna da; PINTO, Ana Beatriz Manhães Pinto. Quissamã: um município petrorentista. In: PIQUET, Rosélia; SERRA, Rodrigo. Petróleo e região no Brasil. O desafio da abundância. Rio de Janeiro: Ed. Garamond, 2007

ENDLICH, A. Pensando os papéis e significados das pequenas cidades. São Paulo: UNESP, 2009.

FRANKS, D. Avaliação do impacto social de projetos de exploração de recursos. Perth, Austrália: International Mining for Development Centre, 2012. Disponível em: http://www.im4dc.org. Acesso Agosto de 2018.

HERCULANO, S. Resenhando o debate sobre justiça ambiental: produção teórica, breve acervo de casos e criação da rede brasileira de justiça ambiental. Revista Desenvolvimento e Meio Ambiente. Curitiba, no 5, p. 143-149, 2002. Disponível em: https://revistas.ufpr.br/made/article/view/22124. Acesso em Junho de 2018.

IBGE - Instituto Brasileiro de Geografia e Estatística. IBGE Cidades. Disponível em: http://www.ibge.gov.br. Acesso em Agosto de 2018.

INFOROYALTEIS - Mestrado em Planejamento Regional e Gestão de Cidades. Inforoyalties: petróleo, royalties e região. Campos dos Goytacazes: UCAM. Disponível em: http://inforoyalties.ucam-campos.br/. Acesso em Agosto de 2018.

JURADO DA SILVA, P.; SPOSITO, E. Cidades pequenas: perspectivas teóricas e transformações socioespaciais. Jundiaí/SP: Paco Editorial, 2013.

LEMOS, L.; NEVES, R. Royalties do petróleo e políticas públicas de fomento agropecuário: uma interpretação à luz da "doença holandesa". Revista Geográfica da América Central. Costa Rica, 2011, p. 1-16. Disponível em: http://www.revistas.una.ac.cr/index.php/geografica/article/view/2511. Acesso em Agosto de 201.

MOTA, A; et al. Impactos socioeconômicos da instalação do polo petrolífero de Macaé/RJ. In: PIQUET, R; SERRA, R. (orgs.). Petróleo e região no Brasil. O desafio da abundância. Rio de Janeiro: Ed, Garamond, 2007.

PAGANOTO, F. Mobilidade e transporte em Macaé/RJ: a "capital do petróleo". Dissertação (Mestrado em Geografia). Programa de Pós-Graduação em Geografia - UFRJ, Rio de Janeiro, 2008.

PESSANHA, R. A relação transescalar e multidimensional petróleo-porto como produtora de novas territorialidades. Tese (Doutorado em Políticas Públicas e Formação Humana). Programa de Pós-Graduação em Políticas Públicas e Formação Humana - UERJ, Rio de Janeiro, 2017

PETROBRAS - Petróleo Brasileiro S.A. Bacia de Campos. Página Inicial. Disponível em: http://www.petrobras.com.br/pt/nossas-atividades/principais-operacoes/bacias/bacia-de-campos.htm.

Acesso em Outubro de 2019. 
PETROBRAS - Petróleo Brasileiro S.A. Relatório Final do Diagnóstico Participativo do PEA-BC. Rio de Janeiro: Petrobras, 2012.

PIQUET; R. O lugar do regional na indústria do petróleo. Revista Brasileira de Estudos Urbanos e Regionais. Recife, v. 14, no 1, 2012. Disponível em: http://rbeur.anpur.org.br/rbeur/article/view/1905. Acesso em Junho de 2018.

PNUD - Programa das Nações Unidas para o Desenvolvimento. Atlas do Desenvolvimento Humano no Brasil 2013. Disponível em: http://www.atlasbrasil.org.br/2013/. Acesso em Agosto de 2018.

QUINTAS, J. Introdução à gestão ambiental pública. 2o ed. revista. Brasília: IBAMA, 2006.

SANTOS, A. Política urbana no contexto federativo brasileiro: aspectos institucionais e financeiros. Rio de Janeiro: EdUERJ, 2017.

SANTOS, M. Espaço e sociedade. Petrópolis: Ed. Vozes, 1982.

SERRA, R. Concentração espacial das rendas petrolíferas e sobrefinanciamento das esferas de governo locais. In: PIQUET, R; SERRA, R. (orgs.). Petróleo e região no Brasil. O desafio da abundância. Rio de Janeiro: Ed. Garamond, 2007.

SERRA, R.; TERRA, D.; PONTES, C. Os municípios petro-rentistas fluminense: gênese e ameaças. Revista Rio de Janeiro. Rio de Janeiro, no. 18-19, jan-dez, 2006. Disponível em: http://www.forumrio.uerj.br/documentos/revista_18-19/Cap-3-Rodrigo_Denise_Carla.pdf. Acesso em Agosto 2018.

SILVA, A.; GOMES, R.; SILVA, V. Por uma concepção conceptual: as cidades pequenas em tela. In: SILVA, A.; GOMES, R.; SILVA, V. Pequenas cidades: uma abordagem geográfica. Natal: EDUFRN, 2009.

SOUZA JUNIOR, G. Doença holandesa: o Brasil corre esse risco? Jornal Eletrônico da Faculdade de Economia das Faculdades Integradas Vianna Junior. Juiz de Fora, 2ㅇ Semestre 2008. Disponível em: https://revistas.fee.tche.br/index.php/indicadores/article/viewFile/2951/3214. Acesso em Junho de 2018.

VEIGA, J. Cidades imaginárias: o Brasil é menos urbano do que se calcula. Campinas: Autores Associados, 2002. Disponível em: http://www.scielo.br/pdf/In/n87/07.pdf. Acesso em Agosto 2018. 